\title{
Slovenski prognanici u Nezavisnoj Državi Hrvatskoj
}

\author{
BARBARA RIMAN \\ Inštitut za narodnostna vprašanja \\ Ljubljana, Slovenija \\ barbara.riman@guest.arnes \\ FILIP ŠKILJAN \\ Institut za migracije i narodnosti \\ Zagreb, Hrvatska \\ filip.skiljan@imin.hr
}

Problematika prognanoga slovenskog stanovništva s prostora koji je tijekom Drugoga svjetskog rata okupirao Treći Reich prisutna je u hrvatskoj, slovenskoj i srpskoj povijesti, ali je prije svega povezana s iseljavanjem i progonom drugoga (u prvom redu srpskoga) etničkog stanovništva. Ta etapa slovenske povijesti u Hrvatskoj nije dovoljno poznata široj javnosti. Upravo stoga radom se želi upozoriti na veliki broj Slovenaca koji su Drugi svjetski rat preživjeli na prostoru Hrvatske i Bosne i Hercegovine, odnosno tadašnje Nezavisne Države Hrvatske, koja je imala drugačije granice od današnje Hrvatske i Bosne i Hercegovine. U dosad objavljenim radovima o progonu slovenskoga stanovništva u Hrvatsku i Bosnu i Hercegovinu često se zaboravlja na dodatni kulturni šok koji su prognanici doživjeli. Osim opisa djelovanja legalnih institucija koje su bile zadužene za skrb o prognanom slovenskom stanovništvu, u radu su predstavljeni pojedinačni slučajevi iz kojih je vidljiva teška situacija i problemi s kojima su se suočavali stanovnici prognani iz slovenskih krajeva.

Ključne riječi: Drugi svjetski rat; Nezavisna Država Hrvatska; Slovenci; prisilne migracije; slovenski prognanici 


\section{Uvod}

Prošlo se stoljeće naziva „stoljećem svjetskih ratova”, ali i „stoljećem izbjeglica”. Obilježila su ga dva svjetska rata koja su uz velike ljudske gubitke i materijalnu štetu prouzročila i migracije velikih razmjera. Tijekom Drugoga svjetskog rata jednu od skupina prisilnih migracija ${ }^{1}$ obuhvaćaju i deportirani, odnosno prisilni radnici, vojni zarobljenici, „preseljeni” odnosno deportirani, a među njih možemo uključiti i preko 20 tisuća Slovenaca. ${ }^{2}$ Oni su na prostoru Nezavisne Države Hrvatske (NDH) proživjeli neko vrijeme, tu su se suočavali s izrazitim nepovjerenjem, a materijalni uvjeti u kojima su se našli bili su i više nego bijedni. ${ }^{3}$

Ovdje spomenute migracije spadaju u skupinu prisilnih migracija koje su se dogodile u Drugom svjetskom ratu, ali to je još uvijek relevantno i aktualno političko pitanje. Prisilne migracije jedno su od temeljnih pitanja koja još uvijek oblikuju odnose između prošlosti i sadašnjosti, a ponekad su i zabranjena tema. O progonu slovenskoga stanovništva tijekom Drugoga svjetskog rata istraživalo se, ali znanstvenici su prije svega iskazali interes za povijesnu demografiju te je ona stavljena u politički kontekst, a procesi progona, život pojedinaca u novoj okolini i teškoće s kojima su se susretali stavljeni su u drugi, manje važan plan. Povjesničari su progon slovenskoga stanovništva analizirali i smještali u kontekst organiziranoga prisilnog iseljavanja, ali nisu obraćali pozornost na pojedinačne sudbine.

1 BADE, Evropa v gibanju, 255-256.

2 Istraživači ove problematike ne slažu se oko broja iseljenih Slovenaca te bez obzira na dosadašnja istraživanja on još uvijek varira. U literaturi postoje različita odstupanja. Najčešće se navodi da je u NDH iseljeno oko 10.000 Slovenaca. Prema podacima predstavnika NDH pri Štabu za preseljavanje u Mariboru, do 29. rujna 1941. preseljeno je u NDH sa slovenskoga područja između $10.200 \mathrm{i}$ 10.342 ljudi. Prema podacima Državnoga ravnateljstva za ponovu, ujesen 1941. na području NDH bilo je između 8446 i 8892 slovenskih doseljenika. Prema Državnoj komisiji za utvrđivanje ratnih zločina okupatora i njihovih pomagača, oko 7000 Slovenaca iseljeno je u Srbiju i 12.000 u Hrvatsku (NDH) do listopada 1941. godine. Prema podacima Državnoga ravnateljstva, na spomenutom području bilo je naseljeno 10.950 Slovenaca. Na konferenciji u Zagrebu u rujnu 1941. spominje se i 31.341 osoba te 5000 Slovenaca koji su u NDH došli iz Srbije. Zbog velikoga priljeva „ilegalno/ dobrovoljno" useljenih Slovenaca, koji su zapravo bili izbjeglice, Ministarstvo unutarnjih poslova NDH napravilo je u listopadu 1941. popis Slovenaca u NDH koji su došli nakon 10. travnja 1941., a prema tom popisu bilo ih je 19.304. Marica Karakaš Obradov navodi da je to vjerojatno nepotpun popis. Prema njezinim podacima, čini se da je u Hrvatsku i Bosnu i Hercegovinu bilo useljeno ili izbjeglo oko 30.000 Slovenaca. Više o tome vidi u: MILOŠEVIĆ, Izbeglice i preseljenici, 27-50; KARAKAŠ OBRADOV, Novi mozaici nacija, 228-229; FERENC, Okupacijski sistemi na Slovenskem 1941-1945; BRČIĆ, „O iseljavanju Slovenaca u Bosnu 1941. godine”, 301-314; FERENC, Nacistička politika denacionalizacije u Sloveniji; ŠETINC, Izgnanci; KRAMAR, Slovenski izgnanci v Neodvisni državi Hrvaški; ŽNIDARŠIČ, KAPLAN, Spomini in pričevanja; ŽNIDARŠIČ, KAPLAN, Spomini in pričevanja II; ŽNIDARŠIČ, KAPLAN, Spomini in pričevanja III; COLNAR, „Kdo je pomagal izgnancem v Zagrebu?”, 301-303; RYBAR̆, „Izgoni slovenskih duhovnikov leta 1941”, 117-129; KEVO, Veze Međunarodnog odbora Crvenog križa i Nezavisne Države Hrvatske.

3 JELIĆ-BUTIĆ, Ustaše i NDH, 169. 
U radu se želi prikazati teškoće i izazove s kojima su se prognanici susretali te kulturni šok koji su neki od njih doživjeli. Svaki rat vrijeme je tragičnih i teških sudbina, ali kad je stanovništvo prognano u drugu sredinu, tada te situacije postaju dodatno teške. Na temelju prikupljenih podataka o pojedincima koji nisu imali veći politički utjecaj može se stvoriti slika i prikazati situacija među slovenskim prognanicima u NDH tijekom Drugoga svjetskog rata.

Podaci su prikupljeni iz pregledanoga arhivskoga gradiva koje se nalazi u Arhivu Republike Slovenije u Ljubljani (u fondovima Slovenski izseljeniški odbor Zagreb 1941-1945 i Urad za podržavljeno lastnino Nezavisne države Hrvatske v Zagrebu). Dopunjeni su podacima iz Hrvatskoga državnog arhiva (u fondu Ministarstvo državne riznice NDH). Osim primarnih izvora uporabljena je i suvremena slovenska i hrvatska znanstvena i stručna literatura koja se bavi ovom problematikom. Pregledane su i tiskovine onoga vremena, a podacima iz njih dodatno je ilustriran položaj slovenskih prognanika na prostoru NDH.

Drugi svjetski rat i slovensko stanovništvo preseljeno na prostor Nezavisne Države Hrvatske

Slovensko etničko područje bilo je tijekom Drugoga svjetskog rata podijeljeno među tri okupatorske države. Mađari su više tisuća Slovenaca uglavnom deportirali u koncentracijski logor Sárvár, a u tzv. Ljubljanskoj pokrajini, koja je bila pod talijanskom vlašću, interniranih i poslanih u logore bilo je između 25 i 30 tisuća, odnosno 7-9 posto stanovništva. ${ }^{4}$ Prema prvotnom planu, s njemačkoga okupacijskog područja trebala je biti protjerana približno trećina stanovništva, točnije od 220 do 260 tisuća Slovenaca, a plan se trebao provesti u tri faze: 1. progon Slovenaca, 2. kolonizacija Nijemaca na slovenski prostor i 3. potpuna germanizacija ostatka stanovništva. Među prognanima su trebali biti i koruški Slovenci, čime bi bilo riješeno i „slovensko pitanje” u današnjoj austrijskoj Koruškoj. ${ }^{5}$ Svi planovi nisu ispunjeni. Od samoga su početka bili nerealni, ali njihovi idejni začetnici susretali su se i s raznim problemima.

Sastanci na kojima se razmatralo kako riješiti pitanje slovenskoga stanovništva na okupiranom području koje je zauzela njemačka vojska započeli su već u svibnju 1941., ${ }^{6}$ a završeni su na konferenciji u Zagrebu 4. lipnja 1941. godine. Dogovoreno je da će se na prostor NDH doseliti onoliko Slovenaca koliko će Srba biti iseljeno u Srbiju. ${ }^{7}$

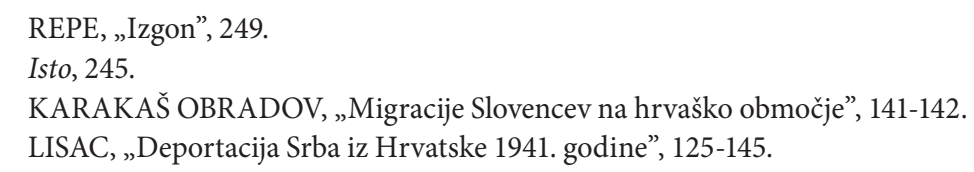


Na konferenciji u Zagrebu dogovoreno je i da će se iseljavanje odvijati u tri vala od 7. lipnja do 31. listopada 1941. godine. U prvom valu, koji je trajao do 5. srpnja, planiralo se iseliti oko 5000 Slovenaca, i to uglavnom profesora, učitelja te drugih politički utjecajnih i javnih osoba, i to izravno u Srbiju, a katoličke svećenike iz Slovenije u NDH. U tom prvom valu u NDH je naseljeno 349 svećenika, koji su bili raspoređeni po samostanima i župama u Slavonskoj Požegi i Zagorju. ${ }^{8}$ Drugi val iseljavanja trajao je od 10. srpnja do 30 . kolovoza i u njemu je planirano iseljavanje oko 25 tisuća Slovenaca, a treći val, od 15. rujna do 31. listopada, trebao je obuhvatiti oko 65 tisuća slovenskih seljaka s prostora Donje Štajerske te oko 80 tisuća seljaka iz Koruške. ${ }^{9}$ Treći se val nije dogodio i to je stanovništvo iseljeno na područje današnje Njemačke i Poljske. ${ }^{10}$ I danas se ne zna točan broj stanovnika preseljenih na prostor NDH jer su nakon doseljavanja često mijenjali mjesto boravka. Tijekom rata određene pojedince pronašli smo u različitim krajevima $\mathrm{NDH}$. Na to su utjecale ratne okolnosti i borbe koje su vođene, te je stanovništvo od nadležnih u NDH zahtijevalo preseljenje u mirnije krajeve. Pojedinci su se često selili. Samo iseljavanje za slovensko stanovništvo bilo je dodatno otežano jer nije postojao organ koji bi rješavao brojne probleme koji su se pojavljivali prilikom progona. Zato je Vlada NDH uskoro osnovala poseban ured - Odjel za preseljavanje i naseljavanje pučanstva, koji je nakon četiri dana djelovanja ukinut, a potom je za istu problematiku osnovano Državno ravnateljstvo za ponovu ${ }^{11} \mathrm{~s}$ Josipom Rožankovićem kao ravnateljem. Zadatak mu je bilo sređivanje svih poslova „useljavanja, smještaja i izseljavanja pučanstva” i „preuzimanje i predaja posjeda i inih dobara iz ruku izseljenih u ruke useljenih". ${ }^{12}$ Uskoro je osnovano DrŽavno ravnateljstvo za gospodarstvenu ponovu, koje je 1. srpnja 1941. preuzelo poslove Ureda za obnovu privrede. Oba su ravnateljstva preuzimala imovinu iseljenih i osoba koje su napustile $\mathrm{NDH} .^{13}$

Državno ravnateljstvo za ponovu odaslalo je 9. srpnja 1941. „Upute o useljavanju i smještaju Slovenaca” svim kotarskim predstojnicima, gradskim i općinskim načelnicima te ustaškim logornicima, a one su dopunjene 14. srpnja.

\footnotetext{
8 O problematici svećenstva vidi: GRBEŠIĆ, „Prihvat prognanih slovenskih svećenika”; ŠKVORĆEVIĆ, Gostoprimstvo Katoličke crkve; ARMANDA, „Nadbiskup Alojzije Stepinac”; BATELJA, Blaženi Alojzije Stepinac i dr.

9 FERENC, „Razvoj prebivalstva”, 278; KARAKAŠ OBRADOV, „Migracije Slovencev na hrvaško območje", 143.

10 ŠKILJAN, Organizirana prisilna iseljavanja Srba iz NDH, 279.

11 Državno ravnateljstvo za ponovu imalo je u svojem djelokrugu sređivanje svih poslova useljavanja, smještaja i iseljavanja pučanstva, preuzimanje i predaju posjeda i ostalih dobara iz ruku iseljenih u ruke koloniziranih te pripremnu upravu na takvim imanjima i dobrima (HEĐBELI, „Ponova”, 512).

12 KARAKAŠ OBRADOV, Novi mozaici nacija, 207.

13 Isto.
} 
U pojedine kotareve trebalo je od srpnja do 31. listopada 1941. naseliti oko 2500 Slovenaca. Preporuka je bila smještati preseljenike u „prolazne logore”, koji su bili organizirani u školskim zgradama ili sličnim prostorima, i prema mogućnostima odmah zapošljavati ako su imali kakvu stručnu naobrazbu.

Razni autori koji su se bavili problematikom prognanoga slovenskog stanovništva ističu da su prognanici bili velika radna snaga koja je ostala neiskorištena, prije svega zbog nepovjerenja i straha među lokalnim stanovništvom i zbog nevoljkosti vlasti NDH da zapošljavaju prisilno preseljene Slovence. ${ }^{14} \mathrm{U}$ početku su vlasti izbjegavale zapošljavati prognano slovensko stanovništvo, ali kako je rat odmicao, tako su i oni dobivali sve više prilike pronaći posao.

Prehrana se rješavala prikupljanjem hrane od iseljenika Srba, koja se potom davala doseljenicima. To se rješenje moglo primjenjivati samo u prvom razdoblju, a poslije se pribjegavalo različitim drugim rješenjima. Dodatno je bio objašnjen i postupak ako doseljenik dobiva kuću i posjed, kao i slučajevi ako se smještaju u srpske obitelji. Ako su Slovenci dobili posjed, o primopredaji je trebalo voditi detaljan zapisnik (popis pokretne i nepokretne imovine), a doseljenici su svojim potpisom jamčili za preuzetu imovinu. ${ }^{15}$

Na području Slovenije vlasti Njemačkoga Reicha osnovale su brojne „prolazne logore” za prihvat Slovenaca u Mariboru, Brestanici, Begunju i Šentvidu. Iz tih logora iseljavalo se prognano stanovništvo u NDH, Srbiju i Njemački Reich. Za stanovništvo iz slovenskih krajeva u NDH je bio namijenjen iseljeničko-useljenički logor u Požegi, koji je služio isključivo sabiranju iseljenika i useljenika. ${ }^{16}$ Prvi transport slovenskih prognanika došao je 1. srpnja 1941., kad logor u Požegi još nije bio do kraja pripremljen za njihov prihvat. Prema sjećanju prognanika, vlakovi bi ih dovezli na željezničku postaju u Slavonsku Požegu te bi odande pješačili u koloni prema naselju Glis. Slavko Alojz Kramar kaže da su ih ustaše tjerali te se iživljavali nad njima vičući: „Brže, stari.”17

Prema navedenim smjernicama, prognani pojedinci mogli su uzeti do 30 kg osobnih stvari (odjeća, pokrivači i sl.), hrane za osam dana, osobne dokumente i 400 dinara gotovine. ${ }^{18}$

U NDH su se pripremali za dolazak slovenskih prognanika. Državno ravnateljstvo za ponovu obavijestilo je svih 140 kotareva o dolasku prognanoga slovenskog stanovništva. Iz dopisa koji je poslan vidljivo je da je Državno rav-

\footnotetext{
14 Milošević u svojem radu donosi detaljan popis zanimanja, pa se uz ostale može spomenuti i 117 željezničara, 152 postolara, 42 policajca, 146 učitelja i profesora, 110 krojača itd. (MILOŠEVIĆ, Izbeglice i preseljenici, 330-331).

15 KARAKAŠ OBRADOV, Novi mozaici nacija, 208.

16 Isto, 27.

17 KRAMAR, Slovenski izgnanci v Neodvisni državi Hrvaški, 21.

18 MILOŠEVIĆ, Izbeglice i preseljenici, 34.
} 
nateljstvo za ponovu pretpostavljalo da bi do 31. listopada 1941. najmanje 2500 Slovenaca bilo smješteno u pojedini kotar. ${ }^{19}$ Mislilo se da će biti smješteni na imanjima prisilno iseljenih Srba, odnosno kod Srba koji nisu iseljeni. No i tu su nastajali problemi. Često se događalo da pojedina iseljena sela s većinskim srpskim stanovništvom nisu imala dovoljan broj kućanstava za doseljenike ili srpsko stanovništvo još nije bilo iseljeno. Znali su također biti dodijeljeni srpskim obiteljima koje su čekale iseljavanje i često su te slovenske obitelji bile veliki teret Srbima. Navodi se da se te slovenske obitelji nisu uvijek brinule za sebe, odnosno da su bile na prehrani kod Srba. ${ }^{20}$ Kao moguće rješenje poslije se zahtijevalo i naseljavanje u domove njemačkih ${ }^{21}$ i židovskih obitelji. ${ }^{22}$ Često su bili naseljavani i u kuće „iseljenih” Roma. ${ }^{23} \mathrm{U}$ situacijama kada nisu znali kamo smjestiti prognano slovensko stanovništvo neki prijedlozi vlasti bili su improvizacija, pa su ustaške vlasti npr. planirale doseljenike naseliti u manastir Pakra, gdje su se trebali brinuti za obrađivanje manastirske zemlje, skupljanje plodova i dr. ${ }^{24}$ To nije bio jedini takav prijedlog: postojala je ideja da se slovensko stanovništvo naseli i u manastire Šišatovac i Kuveždin. ${ }^{25}$ Kada je situacija dopuštala, po jedna je obitelj bila poslana u prazno kućanstvo srpske obitelji, a cijeli se postupak bilježio u obrasce. ${ }^{26}$

Problem pri prihvaćanju doseljenoga slovenskog stanovništva bio je i u tome što su Slovenci doživljavani kao kulturno napredniji od Hrvata rimokatoličke i islamske vjeroispovijesti (iz perspektive NDH) u tim krajevima, pa su kotarske vlasti pojedinih dijelova NDH predlagale da ih se naseli $\mathrm{u}$ „kulturno razvijenije krajeve”. Osim toga smatrali su da se Slovenci kao rimokatolici ne bi uklopili u kotareve u kojima većinu čine muslimani ili pravoslavci. ${ }^{27}$ Tako je Državno ravnateljstvo za ponovu odustalo od naseljavanja Slovenaca u Dalmaciju, ${ }^{28}$ Hercegovinu, istočnu Bosnu i Liku. Na kraju je dogovoreno da će se

\footnotetext{
19 FERENC, Nacistička politika denacionalizacije u Sloveniji, 380.

20 ŠKILJAN, „Prisilno iseljavanje Srba iz Podravine i Kalničkog prigorja”, 356.

21 Takav primjer imamo na području Vinkovaca. Dio Slovenaca trebao je biti smješten u njemačke kuće, primjerice u Jarmini. Ubrzo je reagirao i vođa Njemačke narodne skupine u NDH Branimir Altgayer i uputio prosvjed Ministarstvu vanjskih poslova NDH da nije prihvatljivo da ih se smješta u njemačke kuće te da se, ako nema drugih rješenja, prije dolaska doseljenika razgovara s predstavnicima u njemačkim selima (MILOŠEVIĆ, Izbeglice i preseljenici, 327-328).

22 VUKČEVIĆ, Zločini na jugoslovenskim prostorima u Prvom i Drugom svetskom ratu, 456.

23 KARAKAŠ OBRADOV, Novi mozaici nacija, 218.

24 ŠKILJAN, Organizirana prisilna iseljavanja Srba iz NDH, 265.

25 Isto, 296.

26 KARAKAŠ OBRADOV, Novi mozaici nacija, 212.

27 MILOŠEVIĆ, Izbeglice i preseljenici, 335.

28 Kao primjer se može spomenuti situacija u kotaru Metković, gdje su Slovenci trebali biti naseljeni samo u pravoslavne kuće, kojih je bilo relativno malo, a pravoslavci nisu bili iseljeni iz kotara. Stoga je kotar Metković zahtijevao da se broj doseljenih Slovenaca smanji na najmanju moguću mjeru (SI-AS-1907-UPL NDH, kut. 6, 1197/1941).
} 
od 140 kotareva prognano slovensko stanovništvo naseliti u njih 55. Slovenci nisu naseljavani ni u kotareve uz hrvatsko-slovensku granicu jer su vlasti $\mathrm{NDH}$, ali i njemačke, smatrale da bi na taj način imali vezu sa starim krajem i mogli utjecati na hrvatsko stanovništvo uz granicu (i kulturno i politički). ${ }^{29}$ Mnogi kotarevi nisu bili u stanju primiti toliko ljudi, pa su predlagali smještaj određenoga manjeg broja Slovenaca na svojem području. ${ }^{30}$

Fikreta Jelić-Butić piše da je prisilni smještaj bio toliko neorganiziran da se može govoriti o pravom teroru vlasti NDH nad Slovencima. O teškom položaju svjedočili su i dopisi Ravnateljstva za ponovu iz srpnja 1941. godine:

„Doseljenici smješteni su u vrlo oskudne prostorije, a najveći dio ih je još i danas u školama, šupama i sličnim prostorijama sela i gradova. Ti ljudi gladuju, bolesni su, a veći dio osobito staraca, neće dugo poživjeti. U skoro vrijeme ostat će svi goli i bosi, jer su donešeni novac potrošili, a od nikoga ne primaju ništa. Kad pritisne zima tko zna koliko će ih ostati. Već iz ovoga nastaje pitanje kako ćemo izgledati kada primimo prema ugovoru preostalih 167.000 , kad nismo u stanju smjestiti do danas primljenih 8.000. Naglasujemo, da kako sami Slovenci tako i narod u kotarevima gdje smo ih smjestili pita što će s njima biti jer se nitko za njih ne brine. [...] samoubojstva useljenika očajnika ima već nekoliko."31

Problema s kojima su se suočavale vlasti i preseljeno stanovništvo bilo je mnogo. Iako se predlagalo da se domaće stanovništvo pripremi za dolazak ljudi iz Slovenije, doseljavanje nije uvijek bilo glatko i jednostavno. Najviše vlasti NDH upozoravale su na to da

„[... [ mjesno stanovništvo treba psihološki pripraviti na dolazak useljenika tako, da se istima već unaprijed osigura pristojan postupak i susretljivost od strane starosjedilaca jer su doseljenici dolaskom postali pripadnici Nezavisne Države Hrvatske. Na svaki način mora se spriječiti svaki ispad protiv useljenika i zato valja starosjediocima razjasniti da je njihov dolazak u interesu Države Hrvatske, hrvatskoga naroda, te da se takovo susretanje useljenika zahtjeva sa najvišega mjesta". ${ }^{32}$

Upozoravalo se da pristiglo slovensko stanovništvo treba odmah zaposliti da bi se spriječilo „ljenčarenje”, useljenike je trebalo poticati na učenje hrvatskoga jezika i pravopisa, a opet se s njima trebalo postupati i obzirno jer su postali pripadnici/državljani NDH. Posebno se naglašavalo da ih treba odmah smjestiti u kuće i na posjede srpskoga stanovništva da dugi boravak u iselje-

29 Vidi npr. kotareve Pregrada i Samobor (SI-AS-1907-UPL NDH, kut. 13, 39090/41; SI-AS1907-UPL NDH, kut. 7, 6026/41).

$30 \quad$ Više vidi u: FERENC, Nacistička politika denacionalizacije u Sloveniji, 280-286.

31 Preuzeto iz: JELIĆ-BUTIĆ, Ustaše i NDH, 169.

32 Preuzeto iz: HUZJAN, ,Slovenci u Varaždinu”, 89. 
ničko-useljeničkim logorima ne bi „psihološki nepovoljno djelovao”. ${ }^{33} \mathrm{O}$ teškoj situaciji piše i Slavko Alojz Kramar, danas predsjednik sekcije prognanika u Slovenskom domu u Zagrebu, rođen u Lahoncima kod Ormoža. On kaže da su samoubojstva zabilježena još tijekom boravka u logoru Požega, kao i pokušaji samoubojstva zbog psihičkoga sloma. ${ }^{34}$

Valja napomenuti da nisu svi bili oduševljeni idejom da moraju na prostor kotara useliti 2500 Slovenaca. Prije svih bunile su se vlasti u kotarevima u Lici, Hercegovini i istočnoj Bosni, ali i kotarevi bliži slovensko-hrvatskoj granici. Ujedno se pokazalo da je preseljeno slovensko stanovništvo bilo vrlo nenaklonjeno Trećem Reichu, a svoje neraspoloženje prenosilo je i na lokalno stanovništvo. ${ }^{35}$ Veliki župan Like i Gacke u Gospiću piše negdje u srpnju 1941. godine:

„[...] u interesu čistoće i zaštite rase te prenapučenosti žiteljstva u Lici bilo bi vrlo štetno naseljavati strani elemenat dok imamo svoga na pretek, ukoliko je useljenje u Liku Slovenaca neotklonivo, potrebno je prije svega pronaći mogućnost da se ovdašnje vlahe, tzv. Srbe planskim i brzim putem iseli, [...] u ovoj župi se nalaze dva centralna (za čitavu državu) logora za Židove i Vlahe u kojima ih imade nekoliko tisuća, a dnevno ih stiže po dvije sto do tristo ljudi, pa hrane nema niti za najnužnije[... $]^{336}$

Slično piše i kotarski predstojnik iz Grubišnog Polja:

„Kada se uzme u obzir da Slovenci, koji bi imali naseliti u ovaj kotar dolaze iz Slovenije odakle su prisilno odstranjeni smatraju Njemačku svojim neprijateljem i kada dolaze u Hrvatsku koja je vezana uskim prijateljskim vezama sa Njemačkom, da će Hrvatsku također smatrati svojim neprijateljem onda se mora doći do jasnog zaključka da će se ti Slovenci odmah sprijateljiti sa ovdašnjim Srbima i da će s njima zajedno raditi protiv Hrvata i Nezavisnoj Državi Hrvatskoj. Istodobno dakle sa dolaskom Slovenaca u ovaj kotar povećao bi se u kotaru i broj državnih neprijatelja koji je i onako prevelik. Istina, predvidjeno je da se iz ovog kotara izseli stanoviti broj Srba pa ako se to i dogodi onda još uvijek navode isti razlozi proti useljivanja Slovenaca. Srba naime imade u ovom kotaru 11.000, pa uzmemo li da ih bude odseljeno polovica ostati će ih još uvijek oko 6.000 , pribrojimo $\mathrm{k}$ tome 2.500 Slovenaca imati ćemo opet u kotaru 8.500 Srba i Slovenaca naprama 7.000 Hrvata. Hrvati bi dakle opet bili u velikoj manjini i ugroženi od tako velikog broja državnih neprijatelja." ${ }^{{ }^{37}}$

\footnotetext{
33 KARAKAŠ OBRADOV, Novi mozaici nacija, 210-212.

34 KRAMAR, Slovenski izgnanci v Neodvisni državi Hrvaški, 23.

35 MILOŠEVIĆ, Izbeglice i preseljenici, 332.

36 ŠKILJAN, Organizirana prisilna iseljavanja Srba iz NDH, 282.

37 Isto, 283-284.
} 
Često se na doseljeno slovensko stanovništvo gledalo kao na određenu prijetnju te se zahtijevao pojačan nadzor i u logorima i u kotarevima u koje su smješteni. Napominjalo se da među njima ima „ljudi raznih političkih orijentacija koje su protivne političkoj orijentaciji naše države". ${ }^{38}$ Vlasti NDH bile su nesklone naseljavanju Slovenaca u kotareve na državnoj granici kao što su Samobor, Klanjec i Ludbreg, a na tome je inzistirala i njemačka strana jer bi useljenici tako bili blizu slovenskoga područja i postojala je mogućnost da se sami ilegalno prebacuju natrag. Vlasti NDH također su procjenjivale da to ne bi bilo ni u političkom ni u gospodarskom interesu NDH. U slučaju Samobora čak je rečeno da nema iseljenih srpskih sela u koja bi se smjestilo Slovence iz Štajerske, a i da je to najpasivniji kotar u Velikoj župi Prigorje..$^{39}$ Kotarska oblast u Samoboru smatrala je da naseljavanje Slovenaca uz samu granicu sa Slovenijom nije mudra ideja jer bi tako Slovenci ostali u kontaktu sa starom domovinom i bilo bi onemogućeno "hrvatiziranje toga elementa” ${ }^{40}$ a slično je bilo mišljenje i za Hum na Sutli. Ondje je bilo naglašeno da ako se želi odgajati stanovništvo u hrvatskom duhu, tamo ne treba biti nijednoga Slovenca bez obzira na to je li radnik, trgovac ili svećenik..$^{41}$

Potrebno je naglasiti i da su prisilno iseljeni Slovenci na području NDH Zakonskom odredbom o stjecanju zavičajnog prava osoba iz bivše Slovenije od 11. studenog 1941. dobili pravo da steknu zavičajno pravo u općini svojega prebivališta ako to od dotične općine zatraže u roku od šest mjeseci nakon stupanja te zakonske odredbe na snagu. ${ }^{42}$ Krajem 1942. Pavelić je objavio naredbu da se svi slovenski preseljenici državni činovnici mogu primati u državnu službu. ${ }^{43}$ To je uvelike olakšalo položaj slovenskih prognanika.

U ondašnjim slovenskim novinama nije se pisalo o preseljavanju i iseljavanju, kao ni o problemima s kojima se prognano stanovništvo susretalo. $\mathrm{Na}$ određeni način ta je tema u dnevnom tisku na slovenskom jeziku u ono vrijeme bila zabranjena. Pisalo se o radnim mjestima koja su Slovenci dobili u NDH (o tome se detaljno izvješćivalo), ali drugi podaci ili opisi života tih pojedinaca nisu pronađeni. Tijekom cijeloga tog procesa naglašavalo se da je pojedincima potrebno pronaći posao, te da useljenike potrebno poticati, da uče hrvatski jezik, nisu smjeli raditi bez naknade te se očekivalo da za svaki rad budu plaćeni. ${ }^{44}$

\footnotetext{
Preuzeto iz: JELIĆ-BUTIĆ, Ustaše i NDH, 169.

KARAKAŠ OBRADOV, Novi mozaici nacija, 207.

ŠKILJAN, Organizirana prisilna iseljavanja Srba iz NDH, 284.

FERENC, Nacistička politika denacionalizacije u Sloveniji, 208.

MATAIĆ, Zakoni, zakonske odredbe i naredbe proglašene od 30. listopada do 20. studena 1941, 187.

FERENC, Nacistička politika denacionalizacije u Sloveniji, 400.

KARAKAŠ OBRADOV, Novi mozaici nacija, 210.
} 


\section{Odbor za slovenske useljenike u Zagrebu}

Iznimno važnu ulogu imao je Odbor za slovenske useljenike (dalje: Odbor). Osnovan je u listopadu 1941. pri Useljeničkom odjelu Ureda za podržavljeni imetak Državnoga ravnateljstva za gospodarsku ponovu. ${ }^{45}$ Djelovao je u smjeru poboljšanja položaja slovenskih iseljenika u NDH. Osnivanje Odbora uslijedilo je na inicijativu Krunoslava Draganovića. U Odboru su djelovali Draganović kao predsjednik, koji je još od travnja 1941. surađivao s predstavnicima Hrvatskoga Crvenoga križa i Slovenskoga Crvenog križa, Franjo Harazim kao potpredsjednik, odvjetnik iz Celja Anton Ogrizek ${ }^{46}$ kao blagajnik, tajnik je bio svećenik Jakob Richter iz Maribora, a članovi su bili svećenik Drago Oberžan iz Maribora te industrijalac Josip Žinigoj iz Trbovlja (tada u $\mathrm{NDH}) .{ }^{47} \mathrm{U}$ Odboru je djelovao i veliki broj zagrebačkih Slovenaca, od kojih se kao posebno aktivni u Odboru spominju Viljem Bizjak i Vekoslav Mervar. ${ }^{48}$

Poslovanje Odbora vodio je Jakob Richter, koji je napisao i knjigu o djelovanju Odbora ${ }^{49} \mathrm{a}$ on je zajedno s Antonom Ogrizekom primio više tisuća molbi koje se čuvaju u Arhivu Republike Slovenije u Ljubljani u fondu Slovenski izseljeniški odbor Zagreb 1941-1945. Odbor je izgnanim Slovencima pomagao novčanim sredstvima, odjećom, obućom, hranom te pribavljanjem različitih propusnica. Pomoć je sam Odbor dobivao od raznih drugih institucija. Prema informacijama, Odbor je do kraja 1943. prognanim Slovencima podijelio 4.008.318 kuna te im poslao oko 1500 paketa različitih potrepština. ${ }^{50}$ Navodi se i da je oko dvjesto slovenskih obitelji dobilo zemlju i da je Odbor mnogo učinio za pojedince koji su dobili zaposlenje u državnim službama. Dnevno su primali po sto stranaka, a Odbor je riješio i preko $6000 \mathrm{molbi}^{51}$ koje je dobio od Slovenaca naseljenih u različite dijelove $\mathrm{NDH}^{52}$

Odbor je za svoj rad morao sâm potražiti sredstva. Nešto sredstava dalo je Državno ravnateljstvo za ponovu, ali su se članovi Odbora snalazili i na druge

45 RICHTER, Delo Odbora, 5.

46 O Antonu Ogrizeku nije moguće pronaći mnogo informacija. Bio je odvjetnik iz Celja i politički aktivna osoba. Za zastupnika u Skupštini Jugoslavije izabran je 1938. za šmarski srez („Izid volitev narodnih poslancev za narodno skupščino", Službeni list /Beograd/, 14. 1. 1939., 1). Osim što je bio aktivan u Zagrebu, vidljivo je da je početkom Drugoga svjetskog rata bio u Ćupriji („Pozdrav iz Srbije pošiljajo”, Slovenec/Ljubljana/, 24. 8. 1941., 3). Prema podacima iz knjige Jere Vodušek Starič Prevzem oblasti 1944-1946, strijeljan je na vojnom sudu 1945. godine.

47 KARAKAŠ OBRADOV, Novi mozaici nacija, 209.

48 V. Z., „Prava bratska ljubezen”, Vigred-Vestnik (Ljubljana), svibanj 1944., 88. Vidi i: AKMADŽA, Krunoslav Draganović.

49 RICHTER, Delo Odbora.

$50 \quad$ Isto, 10.

51 V. Z., „Prava bratska ljubezen”, Vigred-Vestnik, svibanj 1944., 88.

${ }_{52}$ O djelovanju Odbora pisale su i tadašnje novine: „Skrb za slovenske naseljence na Hrvaškem”, Jutro (Ljubljana), 29. 2. 1944., 2. 
načine. Tako su npr. od postolara Franje Glavača u Varaždinu kupili 750 pari starih cipela. Zajednica za kožu darovala je 3000 starih dječjih cipela. Veću količinu donjega rublja darovao je Zavod za kolonizaciju: kupili su $1360 \mathrm{~m}$ raznoga tekstila.

Njemačka policija i vlasti NDH često su pravile probleme članovima Odbora, a 1943. njemačka policija zatvorila je Jakoba Richtera zbog rada u Odboru. Odbor je djelovao i poslije, ali je imao drukčiju strukturu organizacije. Tako je na čelu bio Franjo Harazim, a potpredsjednik je postao Viljem Bizjak, zagrebački industrijalac slovenskoga podrijetla. Odbor je zbog nesimpatiziranja vlasti NDH tijekom prvih mjeseci 1945. zatvoren, ali je njegov rad obnovljen netom prije propasti NDH u travnju 1945. godine. ${ }^{53}$

Osim Odbora, pomoć je nudilo i jedino legalno slovensko društvo, koje je vodio Pavle Horvat ${ }^{54}$ - Slovenska kmečko-delavska sloga ${ }^{55}$ te dva doma za useljenike: Dom slovenskih useljenika (Dom slovenskih preseljencev) u Osijeku i Banjoj Luci. ${ }^{56}$ Za banjalučki dom poznato je da je djelovao i 1944. te da je tada imao pedesetak starih i onemoćalih korisnika. ${ }^{57}$

Djelovanje doma u Osijeku povezano je sa slovenskim društvima koja su djelovala u Slavoniji tijekom i neposredno prije Drugoga svjetskog rata. Za Dom slovenskih useljenika / Dom slovenskih preseljencev / Dom slovenskih izseljencev „Osijek (Osiek)” zna se da mu je predsjednik bio Rudolf Bradač, ${ }^{58}$ koji je tijekom boravka u Osijeku bio zaposlen u tamošnjoj podružnici Ureda za kolonizaciju. ${ }^{59}$ Društvo se brinulo za Slovence koji su se našli na području Osijeka $^{60}$ i okolice tijekom Drugoga svjetskog rata. U takvu obliku djelovalo je do svibnja 1945., a iste se godine preimenovalo i postalo podružnica Slovenskoga kulturnog društva „France Rozman” iz Beograda. ${ }^{61}$

\footnotetext{
53 FERENC, Nacistička politika denacionalizacije u Sloveniji, 398-400.

54 O Pavlu Horvatu vidi više u: B. RIMAN, K. RIMAN, „Pavle Horvat”, 233-251.

55 Više o djelovanju društva vidi u: RIMAN, Slovenska društva u Hrvatskoj, 208-215.

56 KARAKAŠ OBRADOV, Novi mozaici nacija, 209.

57 V. Z., „Prava bratska ljubezen”, Vigred-Vestnik, svibanj 1944., 88.

58 Rudolf Bradač rođen je u selu Račice kod Divače 1884. godine. Otišao je u Beč, gdje je izučio za ključara. Najprije je službovao u policiji u Trstu, a 1920. otišao je u Celje. Godine 1941. bio je prognan u Osijek, gdje je radio pri Uredu za kolonizaciju. Umro je 1952. u Celju, kamo se vratio nakon Drugoga svjetskog rata. „Rudolf Bradač - 60-letnik”, Jutro, 1. 4. 1944., 4; „Rudolf Bradač”, Savinjski vestnik (Celje), 12. 7. 1952., 4.

59 Osim njega u podružnici su djelovali i Danica Debenjak, Hilda Dobrila, Jurij Selmajer, Nada Bušelič, Dragica Sekošan i Hermina Divald („Nove nastavitve Slovencev v NDH”, Slovenec, 15. 1. 1943., 3). Za sve je naznačeno da su Slovenci.

60 Tijekom Drugoga svjetskog rata u Osijeku je postojalo vrlo živahno i dobro organizirano tajno djelovanje doseljenoga slovenskog stanovništva. Prije svega se održavala mreža među slovenskim prognanicima, a posebnu ulogu imali su Ferdo Delak i Slavko Klančar (RIMAN, „Delovanje Slovencev v Osijeku", 149).

61 RIMAN, Slovenska društva u Hrvatskoj, 208-215.
} 
Molbe slovenskih prognanika Odboru za slovenske useljenike - slika života izgnanih Slovenaca u Nezavisnoj Državi Hrvatskoj

Sve dosad izneseno moguće je ilustrirati i potvrditi individualnim primjerima s kojima su se suočavali pojedinci koji su se nakon izgona iz svojega zavičaja u NDH našli u nezavidnom položaju. Mali ih je broj dobio imanja iseljenih Srba budući da je kolonizacija Hrvata na srpska imanja u velikoj mjeri već bila provedena. Bilo je pokušaja smještanja slovenskoga stanovništva u različite neprikladne zgrade. Stoga je potpuno jasno da su se Slovenci našli u vrlo lošoj situaciji, bez krova nad glavom, bez zaposlenja, bez ikakvih primanja i s vrlo malim mogućnostima za dobivanje posla. Obitelji koje su napuštale iseljeničko-useljenički logor vozili su dalje vlakovima i kamionima. Slovenske obitelji koje su se odmah preselile u Slavoniju bile su dobro prihvaćene i ostale su cijeli Drugi svjetski rat u istome mjestu, a u mnogo su se težem položaju našle one koje su najprije otišle u Bosnu i poslije se preselile u Slavoniju. U Bosni se ustanak rasplamsao već 1941., pa su brojne slovenske obitelji tražile da ih se odande preseli sjeverno od Save, gdje ustanka još nije bilo. Te su obitelji na neki način poslije ostale prepuštene same sebi. ${ }^{62}$

Mnogi su bili smješteni u srpskim obiteljima koje nisu bile iseljene, a siromašnim srpskim kućanstvima često su bili teret. Mnogi od pristiglih Slovenaca nisu mogli izdržati svoj položaj, pa su padali u očaj i tražili način da se vrate u rodni kraj. U krajevima južno od Save i Kupe Slovenci su se bojali za goli život nakon dizanja ustanka, pa su u više slučajeva tražili da budu premješteni na sigurnija područja, sjeverno od Save. Siromaštvo, glad, nezaposlenost, depresija i oskudica te opća nesigurnost temeljne su značajke života slovenskih obitelji koje su prisilno iseljene iz Slovenije u NDH.

\section{Egzistencijalni problemi}

Iz svih se pisama na realnim primjerima vidi s kakvim su se sve velikim problemima susretali Slovenci koji su živjeli na prostoru NDH. U kakvim su uvjetima živjeli dobro ilustrira izvještaj koji piše Mihajlo Juriš, koga je Državno ravnateljstvo za ponovu zadužilo da obiđe Slovence u kotarevima Županja, Hrvatska Mitrovica, Đakovo, Osijek i Šid. Zabilježio je da su u Županji krajem 1942. svi prognanici zaposleni, ali nemaju odjeću i obuću, a ni namještaj. Juriš je stoga predlagao da im se podijeli pokućstvo i da se o tome brine Ured za podržavljeni imetak u Županji (očito se radilo o pokućstvu oduzetom Srbima i Židovima). U Hrvatskoj Mitrovici situacija je bila slična, a u Osijeku je problema imalo četrnaest obitelji koje se nije imalo kamo smjestiti jer nije bilo

62 KRAMAR, Slovenski izgnanci v Neodvisni državi Hrvaški, 36. 
stanova, pa su živjeli u logoru za slovenske useljenike. Teško je bilo i u Đakovu, gdje su slovenski useljenici živjeli u logoru i ondje, kako piše Juriš, nisu imali ni slame ni madraca, nego su spavali na podu. ${ }^{63}$

Slična je situacija bila i u drugim krajevima NDH kamo se doseljavalo prognano slovensko stanovništvo. Ilustracije radi, u Sarajevu su prognanici bili zaposleni i u gradskoj upravi, a kotarska ih je uprava smjestila i po srpskim obiteljima u okolici Sarajeva. U Bosanskoj Gradiški vrlo je malo prognanika bilo zaposleno, u Gračanici su porazmještani po srpskim obiteljima u okolici grada, u okolici Petrinje prognanici su živjeli u strahu od partizansko-ustaških sukoba koji su ondje započeli već u srpnju 1941., u okolici Osijeka bili su smješteni u Čepinu, Čepinskim Martincima i Bijelom Brdu po srpskim obiteljima. ${ }^{64}$ Sukobi su bili problem i za 110 slovenskih prognanika koji su prvotno bili u Varcar Vakufu, a krajem rujna 1941. preseljeni su u okolicu Vukovara (sela Gaboš, Ostrovo i Markušica). ${ }^{65}$

Vrlo je teška situacija za slovenske doseljenike bila u logoru u Banjoj Luci, gdje su vlasti NDH tražile da napuste logor iako su uspjeli pronaći zaposlenje. Slovensko stanovništvo nije moglo pronaći drugo mjesto za stanovanje, stoga su zbog neimaštine i nemogućnosti kupnje hrane tražili pomoć od Odbora. O tome da su i Slovenci u NDH bili upoznati s teškom situacijom slovenskih prognanika u Banjoj Luci govori i činjenica da su u suradnji sa Slovenskom kmečko-delavskom slogom prikupljali sredstva da im se pomogne. ${ }^{66}$ Sredstva su se skupljala i u suradnji s društvom Hrvatska žena. ${ }^{67}$

Gledajući cjelokupnu situaciju, zaposlenih osoba u pojedinim obiteljima bilo je malo, pa su životni uvjeti bili vrlo teški. ${ }^{68}$ Radili su kao sluge za pravoslavne stanovnike sela, hranu su nabavljali švercajući, a cijena hrane bila je jako visoka. ${ }^{69}$

Često se događalo i da su članovi obitelji raseljeni po različitim domaćinstvima. Alojz Kramar zapisao je: „Bili smo iseljeni u kotar Bosanski Novi. Ondje su nas najprije raselili u Dvor na Uni, mene i brata u kuću Draginje Đermanovića, oca, mamu i tri brata k obitelji Milana Stanića, baku, tetu i dva strica po drugim kućama u selu Glavičani."70

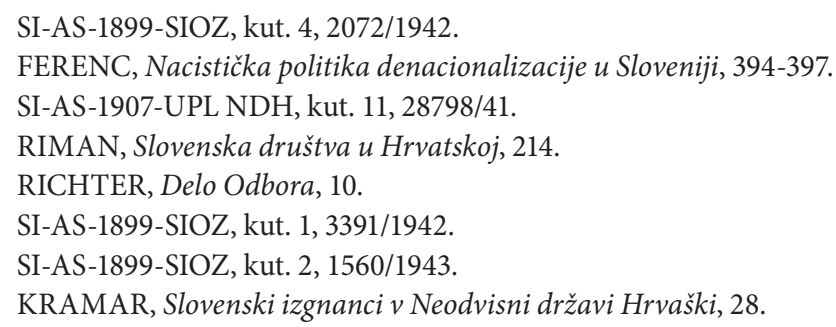


Mnogi prognani Slovenci naseljeni u napuštene srpske kuće bili su pak nezadovoljni standardom jer su se u Sloveniji očito naviknuli na bolje životne uvjete od onih u kojima su se našli. Franc Ferala bio je naseljen zajedno s obitelji od jedanaest članova u kuću u Plavšincu kod Koprivnice. U svojem pismu kaže da ima vrlo brojnu obitelj, a kuća u koju je smješten je nehigijenska, sa zemljanim podom, bez ikakva namještaja. Napominje da cijela obitelj spava na zemlji. U istoj kući bilo je smješteno još dvoje ljudi, koji su dobili najbolje prostorije, za razliku od njegove obitelji. Ferala piše da su strašno siromašni te da iz dana u dan padaju u sve veće siromaštvo. Ferali je Odbor poslao 2.000 kuna. $^{71}$

Kao što je spomenuto, Slovenci u Bosni molili su da budu premješteni u sigurnije krajeve, odnosno u zone gdje nije bilo borbi snaga NDH s ustanicima. Tako su 13. travnja 1942. svi Slovenci iz kotara Sanski Most tražili od Odbora premještaj iz Bosne. Naime, ondje je prekinut željeznički promet, pa su bili odvojeni od ostatka svijeta, a nisu imali ni mogućnost zaposlenja na tom području. ${ }^{72}$ I Jožef Tušek tražio je premještaj iz Visokog za sebe i obitelj u naselje Crnac nedaleko od Podravske Slatine, gdje ga je na stan želio primiti Tomo Radinković. Pismo preporuke napisao mu je kapelan iz Crnca, Slovenac Alojzije Bratuša. Zabilježeno je čak i da su se neke obitelji selile po osam puta, u prvom redu da nađu bolji kraj za život te ostvare i bolje životne uvjete. ${ }^{73}$ Takav je primjer i seljenje obitelji Martina Kačinčika. Njegovu obitelj, koja je imala osmero djece, preseljavali su po čitavoj Baniji i Slavoniji. Isprva su bili u Dvoru na Uni, potom su premješteni u Rajić kod Novske, a iz Rajića u Petrinju, odakle su preseljeni u Četvrtkovac kod Sunje. U Četvrtkovac su došli partizani, pa su neko vrijeme bili u izbjeglištvu, a naposljetku su se vratili u napuštene srpske kuće, gdje su službeno kolonizirani i gdje su dobili 2 jutra zemlje. ${ }^{74}$ Emil Pipan bio je prisilno iseljen u kolovozu 1941. te je smješten u Osijek Vojakovački u kotaru Križevci, u kuću iseljene srpske obitelji. Međutim, u studenom 1941. vlasnici kuće vratili su se u selo, pa je Emilova obitelj preseljena u Rovišće kod Bjelovara. Bio je nastanjen u nekadašnjem parohovu stanu, a sin mu je stupio u oružništvo NDH i služio u 3. oružničkoj pukovniji u Banjoj Luci. Stari roditelji ostali su potpuno sami, bez primanja i pomoći mlađega člana obitelji, pa su tražili pomoć u odjeći ili novcu od Hrvatskoga Crvenoga križa, koji je molbu prenio Odboru. ${ }^{75}$ Obitelj Emila Pipana nije bila jedina u parohijskom stanu. Dijelili su ga s učiteljem Ivanom Bizjakom iz Celja. I on se selio više puta. Naj-

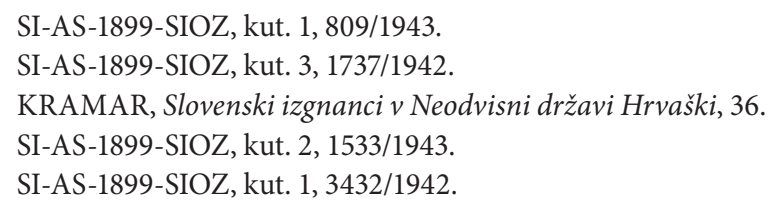


prije je bio u Požegi, pa u Križevcima, zatim u Osijeku Vojakovačkom, potom u Velikim i Malim Sesvetama, u Kraljevcu i tek nakon toga u Rovišću. ${ }^{76}$ Dvije obitelji u parohijskom stanu imale su na raspolaganju dvije sobe.

Nisu to usamljeni primjeri. Ivan Žiberna opisao je da su ga isprva doselili u Cazin, potom je morao otići u Veliku Kladušu, a zbog partizanskoga upada u Veliku Kladušu odselio se u Topusko. U Topuskom nije mogao naći posao, a do najbliže željezničke postaje u Petrinji imao je $35 \mathrm{~km}$ po nesigurnom terenu, pa je molio Odbor neka mu osigura da dobije zaposlenje u Topuskom. ${ }^{77}$

Često je bilo nezadovoljstvo smještajem. Franc Urbančič molio je da ga premjeste iz Visokog u grubišnopoljski kraj s čitavom obitelji (desetero djece i supruga). ${ }^{78}$ Kako su na pojedinim područjima djelovali partizani, slovenski iseljenici morali su se seliti. ${ }^{79}$

Zanimljiv je dopis učitelja Šebarta iz Bukvika kod Brčkog, koji opisuje svoje trenutačno stanje. Tako piše da je Bukvik u rujnu 1942. opkoljen sa svih strana četnicima i od tada pravoslavno stanovništvo više ne želi katolicima prodavati mlijeko, drva i bilo što što im je potrebno. Osim toga u selu se nalazila vojarna, u kojoj je bio i učiteljev stan. Stoga se Šebart bojao da bi mogao stradati ako četnici uđu u naselje. Želio je biti premješten u katoličko naselje. Kaže i da mu je supruga u drugom stanju i već ima jedno malo dijete. Iz sačuvane dokumentacije nije vidljivo je li mu Odbor uspio pomoći da dobije premještaj. ${ }^{80}$

Početkom 1942. pojačano je djelovanje partizana i u brdsko-planinskim dijelovima Slavonije. Stoga je odbornik za Slovence na području kotara Slatina predlagao da Slovenci nastanjeni u potpapučkim selima Voćin, Slatinski Drenovac i Ćeralije što je moguće prije budu premješteni u druge zone zbog neprestanih borbi snaga NDH s partizanima. Predlagao je da se sve Slovence iz toga područja premjesti u Medince, koji se nalaze u ravnici, podalje od žarišta ratnih sukoba. ${ }^{81}$

Mnogi su Slovenci od Odbora tražili propusnice. No Odbor ih nije mogao izdavati, budući da se radilo o privatnoj ustanovi, nego su upućivali pojedince da se obrate „Državnom uredu za preseljenike, odnosno Državnoj riznici, odjelu za useljavanje”. Naime, činjenica je da su pojedine obitelji bile rastav-

76 SI-AS-1899-SIOZ, kut. 1, 909/1943.

77 SI-AS-1899-SIOZ, kut. 1, 3535/1942. U Topuskom i okolici živjelo je 29 obitelji te je vidljivo da su oni dobili i pomoć od Općinskoga poglavarstva u Topuskom u iznosu od 4.148 kuna (HR-HDA-1076, kut. 500, 21348/1941).

78 SI-AS-1899-SIOZ, kut. 3, 81/1941.

79 Činjenica je da slovenski iseljenici nisu masovnije sudjelovali u Narodnooslobodilačkoj borbi u Hrvatskoj. O tome piše: FERENC, Nacistička politika denacionalizacije u Sloveniji, 410-411.

80 SI-AS-1899-SIOZ, kut. 4, 3037/1942.

81 SI-AS-1899-SIOZ, kut. 3, 1394/1942. 
ljene. Naprimjer, Antonija Bezek smještena je u Viroviticu te je tražila da se odobri preseljenje u Viroviticu njezine sestre i svaka, koji su bili u Sarajevu. ${ }^{82}$

Odbor je slao i veće iznose novca za čitave kolonije Slovenaca. U Sušine kod Našica poslao je 7.500 kuna kao potporu. Međutim, interesantno je da nisu svi tamošnji Slovenci bili zadovoljni novcem koji su dobili. Tako je trgovac Senica iz Žalca rekao da neće uzeti 100 kuna potpore jer je to premalo. Ostale slovenske seljačke obitelji u Sušinama i Granicama koje su bile nastanjene na srpska imanja bile su zadovoljne novcem koji su dobile kao potporu. ${ }^{83}$

Loše je bilo i Slovencima u Bugojnu. Onamo je Odbor poslao čak 10.000 kuna za nekoliko obitelji koje su jedva krpale kraj s krajem. Prema izjavi Vladimira Cvetka, ${ }^{84}$ vidljivo je da dnevna naknada koju su Slovenci zarađivali u Bugojnu i okolici nije bila dovoljna ni za hranu. ${ }^{85}$

Da su Slovenci uistinu ostali bez svega nakon odlaska iz svojih domova vidljivo je i iz pisma Valentina Reberšeka ${ }^{86}$ On je imao sreću da se zaposli kao dnevničar u Gotalovu za plaću od 1.700 kuna. Međutim, prilikom odlaska iz Kozjeg u Štajerskoj bio je prisiljen predati svoj namještaj i imovinu Njemačkom Reichu. Kada je stigao u NDH, tražio je da dobije namještaj za sobu u koju je smješten. Tražio je Odbor da mu pomognu pri nabavi namještaja budući da njegova plaća nije dovoljna ni za osnovne stvari. U dopisu nabraja što je sve ostavio u svojoj kući u Kozjem..$^{87} \mathrm{U}$ teškom je položaju bilo i šest slovenskih obitelji u Travniku. „Sve ove obitelji nalaze se u kritičnom položaju: skupoća danomice raste te sa svakim 'pazarnim danom' životne namirnice poskupljuju po pet i više kuna. [...] U ovakvom smo bijednom stanju da čak ni kruha [za Božić, op. a.] nećemo imati." ${ }^{8}$

Da je s hranom bilo jako teško kažu i prognanici koji su poslije zapisali svoja sjećanja. Neki su prosjačili od kuće do kuće, i to ne samo djeca nego i

\footnotetext{
$82 \quad$ SI-AS-1899-SIOZ, kut. 1, 766/1943.

83 SI-AS-1899-SIOZ, kut. 3, 420/1941.

84 Vladimir Cvetko (Vučja Vas, 1910. - Ljubljana, 1988.), urednik, stručni pisac i učitelj. Osnovnu školu pohađao je u rodnom selu, prvi razred državne realke u Mariboru, drugi i treći u Ljutomeru, a državno muško učilište u Mariboru. Maturirao je 1929., a stručni ispit položio 1932. godine. Radio je u Vuzenici, a 1937. postao je školskim upraviteljem. Početkom Drugoga svjetskog rata Nijemci su ga s obitelji iselili u Bosnu. Godine 1943. odlazi u partizane i ondje ostaje do 1945. kada se vraća u Maribor. Djelovao je u Ljubljani (HOJAN, „Cvetko, Vladimir”). Iako je 1942. bio u Neumu (u novinama napisano Neum pri Čapljini), 1943. susrećemo ga u Bugojnu („V prosvetni službi so naslednji Slovenci”, Jutro, 10. 5. 1942., 3).

85 SI-AS-1899-SIOZ, kut. 1, 1097/1943.

86 Zanimljiv je podatak da se nakon Drugoga svjetskog rata vratio u Sloveniju. Živio je u Šmarju pri Jelšah, a umro je 1981. godine. „Valentin Reberšek”, Delo (Ljubljana), 31. 1. 1981., 15.

87 SI-AS-1899-SIOZ, kut. 3, 826/1942.

88 SI-AS-1899-SIOZ, kut. 1, 3446/1942.
} 
majke koje nisu znale kako drukčije prehraniti djecu. ${ }^{89}$ Svakako je potrebno naglasiti i da je dobivanje odjeće i obuće bilo vrlo važno jer prognanici nisu imali osnovne potrepštine. ${ }^{90}$

Odbor je slao i novac. Konrad Čamer, premješten iz Bosanske Gradiške u Sisak, dobio je 1.000 kuna potpore jer nije imao nikakav posao, a u drugom je pismu tražio „nešto odjeće ili cipele“ („kaj obleke, ali čevlje”). ${ }^{91}$

Anton i Angela Bratkovič, koji su živjeli u Rajevu Selu, molili su barem rabljenu odjeću. Naveli su da su sami, da su im sinovi završili u vojsci, „a raditi ne možemo od žalosti za sinovima, potpuno smo oslabjeli“ („a delati ne moreva od žalosti za sinovi sem čisto oslabela”). Angela spominje da će biti do smrti zahvalna Odboru ako joj štogod pošalju. Odbor je tom starom bračnom paru poslao 1.000 kuna. $^{92}$

I drugim nemoćnim starcima Odbor je slao novac kao pripomoć. Trgovac iz Celja Mihael Debenjak zatražio je donje rublje ili „novčanu pomoć“ („denarno potporo"). Prisilno je iseljen u Osijek, a imao je 58 godina i patio od reumatizma i srčane kapi, pa više nije bio sposoban ni za kakav posao. ${ }^{93}$ Zanimljivo je i pismo koje je pater Leopold Grbavac iz kapucinskoga samostana u Osijeku poslao uime obitelji Debenjak. Naime, on ih je jednom prilikom posjetio i zatekao „starog čovjeka Mihaela Debenjaka na postelji teško bolesnog”, a uz njega i njegovu suprugu, također bolesnu. „Sin im je uvojačen, a kći od 18 godina morala se brinuti za njih dvoje staraca." 94

Odbor je prognanicima slao i veće količine robe (obuće i odjeće), ponekad hranu i drva za ogrjev te namještaj. Vincek Bratkovič u Gundincima kod Slavonskog Broda ističe da živi sa sestrom i da je sve što je ponio od odjeće i obuće od kuće već istrošeno, odnosno više nema ni hlača ni obuće. ${ }^{95}$

U posebno teškom položaju našla se obitelj Albina Berse, koja je prisilno iseljena iz Slovenije 17. srpnja 1941. godine. Bez ičega su došli u Sarajevo, a pred zimu 1942. više nisu imali što odjenuti i obuti. U međuvremenu su dobili prvo dijete, koje sad ima devet mjeseci. Albin moli Odbor neka mu pošalju zimski kaput, cipele i zimsko rublje. Iz bilješke na dopisu vidljivo je da im je Odbor poslao nešto zimskoga rublja. ${ }^{96}$

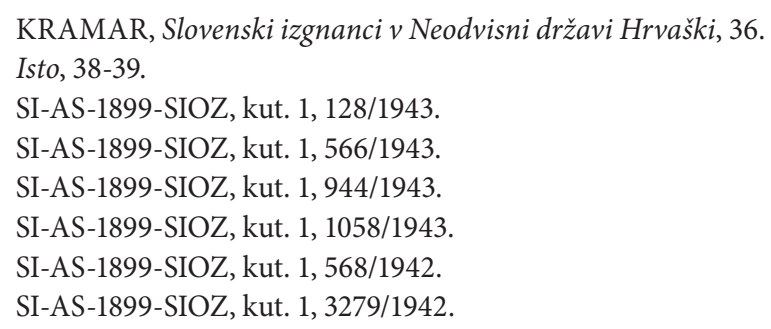


Jože Bajc nalazi se u selu Grk kod Dervente. Iz pisma se vidi da ima maloga sina od dvije godine koji nema što odjenuti. Također moli da djetetu pošalju riblje ulje i dobave drva za grijanje. Odbor je poslao nešto odjeće i obuće te riblje ulje za dijete. ${ }^{97}$

Katarina Erbežnik, koja je živjela u Gračanici, nije mogla kupiti ni cipele svojim kćerima u dobi od jedanaest i trinaest godina. Tražila je od Odbora obuću i odjeću, što je dva tjedna nakon molbe i odobreno i poslano u Gračanicu. ${ }^{98}$

Događalo se da Odbor pošalje robu koja nije odgovarala potrebama onih koji su ju tražili. Tako je Marjan Gombač iz Osijeka tražio da mu pošalju cipele za dvogodišnju kćer, ali je dobio cipele za sedmogodišnju djevojčicu. Te je cipele Gombač darovao drugoj „sirotoj” slovenskoj djevojčici, a od Odbora je ponovno tražio cipelice za dvogodišnjakinju. ${ }^{99}$ Ivanu Kertu, koji je iz Maribora stigao u Sarajevo, ukrali su kaput i cipele. Stoga je zamolio Odbor da mu pošalju cipele i zimski kaput. ${ }^{100}$

Angela Ocepek također je bila u vrlo lošem položaju. Našla se sama s troje djece u Bosanskom Petrovcu. Ondje im je imanje na koje su naseljeni bilo popaljeno, pa su nastavili put prema Slavoniji, u Gundince. Iz Gundinaca je tražila Odbor kakvu odjeću i obuću za svoju djecu. ${ }^{101}$ Jozef Tršelič iz Križevaca piše da ima dvije kćeri, od deset i osam godina, te da će mu se toga mjeseca (lipanj 1943.) roditi treće dijete, a nemaju ni jedne jedine pelene, pa moli Odbor pelene. ${ }^{102}$ Marija Župančič na Državnom dobru Topolovac bila je trudna i čekala da se porodi. Molila je nešto u što bi mogla zamotati dijete kad se rodi. ${ }^{103}$ Situacija u Donjoj Kovačici kod Grubišnog Polja vrlo je teška. Činjenica je da tamošnji Slovenci nemaju što ni krpati ni prati, kako piše u dopisu, budući da je u selu strašno blato, a Slovenci su bez cipela i svi su čitavo vrijeme mokri. Na kraju dopisa stoji popis osoba kojima su potrebne cipele. ${ }^{104}$ Slovencima u Okučanima nitko nije želio pomoći. Iz pisma koje su slali Odboru vidljivo je da je općina smatrala da se Slovenci sami moraju snaći bez obzira na to što nemaju ni odjeće ni obuće ni namještaja. ${ }^{105}$ Antonija Srša bila je smještena $u$ Dubovcu kod Okučana i već je od Odbora dobila 1.000 kuna. Međutim, nije

\footnotetext{
SI-AS-1899-SIOZ, kut. 1, 3289/1942.

SI-AS-1899-SIOZ, kut. 1, 3440/1942.

SI-AS-1899-SIOZ, kut. 1, 982/1943.

SI-AS-1899-SIOZ, kut. 1, 3513/1942.

SI-AS-1899-SIOZ, kut. 1, 384/1943.

SI-AS-1899-SIOZ, kut. 2, 1552/1943.

SI-AS-1899-SIOZ, kut. 1, 528/1943.

SI-AS-1899-SIOZ, kut. 1, 3307/1942.

SI-AS-1899-SIOZ, kut. 1, 56/1943.
} 
imala nikakvu odjeću za jednoga od svojih sinova i sebe, pa je tražila pomoć od Odbora. ${ }^{106}$

U Dubovcu je bio i August Stračanek, čiji sin nije mogao raditi u restoranu jer nije imao cipele. Lokalni postolari tražili su 4.000 kuna za nove cipele, pa je Stračanek tražio pomoć od Odbora. ${ }^{107}$

\section{Zapošljavanje Slovenaca}

Najveći broj prognanika nakon dolaska na područje NDH nije imao zaposlenje. Živjeli su po selima u kojima se nisu mogli baviti ničim osim poljoprivredom (a bilo ih je koji su se doselili kao obrtnici ili državni službenici i nisu znali ništa o poljoprivredi). Stoga je dio prognanika vrlo brzo nakon dolaska ostao bez novca (ušteđevine) i bez mogućnosti za egzistenciju. Mnogi su bili bez osnovnih namirnica, gladni, polugoli i bosi, bez ogrjeva i prepušteni sami sebi. Nisu imali primanja niti mogli dobiti zaposlenje. I kad su dobili zaposlenje uglavnom se tada radilo o slabije plaćenim poslovima bez obzira na njihovo visoko obrazovanje ili bolji status koji su imali u Sloveniji prije rata.. Naprimjer, u Đakovu su pojedinci bili zaposleni u vrtu kod biskupa, kao dvorkinje, šumski radnici, sluge, zemljoradnici, željezničari, činovnici u općini, radnici na pustari i slično. ${ }^{108}$ To je bilo povezano s nepovjerenjem i strahom lokalne zajednice. Situacija se poboljšala nakon 1942., kad je počelo nedostajati radne snage. ${ }^{109}$ Ali svejedno je bilo mnogo više onih koji se nisu uspjeli zaposliti od onih koji su našli zaposlenje. ${ }^{10}$ Slovenci su mogli dobiti posao u državnim službama, ali ne na rukovodećim položajima, a zbog siromaštva i bijede molbe koje su doseljenici podnosili za posao bile su oslobođene državnih biljega. ${ }^{111}$

O Slovencima iseljenim u NDH često su izvještavale i novine, koje su u skladu s tadašnjom politikom idealizirale njihov položaj. Ipak, iz usputnih novinskih obavijesti može se vidjeti da su Slovenci u Hrvatskoj teško živjeli. U tim se člancima mogu pronaći razni zanimljivi podaci, koji potom mogu

\footnotetext{
106 SI-AS-1899-SIOZ, kut. 1, 3918/1942.

107 SI-AS-1899-SIOZ, kut. 1, 3671/1942.

108 SI-AS-1899-SIOZ, kut. 9, 2159/1942.

109 KRAMAR, Slovenski izgnanci v Neodvisni državi Hrvaški, 37.

110 ŠKILJAN, Organizirana prisilna iseljavanja Srba iz NDH, 298.

111 KARAKAŠ OBRADOV, Novi mozaici nacija, 211.
} 
dodatno ilustrirati situaciju u NDH, ${ }^{112}$ a redovito se izvještavalo o tome koji su iseljeni Slovenci dobili zaposlenje u državnoj službi. ${ }^{113}$

U teškoj se situaciji bez zaposlenja našla Marija Brajlih, pa piše Odboru i traži pomoć u novcu. Kaže da je sama u Mečenčanima na Baniji s „dvojicom dječaka”. Moli da ju se premjesti u neko mjesto gdje postoji tvornica u kojoj bi mogla raditi sa starijim sinom. ${ }^{114}$ Ona nije bila jedina u takvoj situaciji. Janez Brlec, otac šestero djece, molio je Odbor za pomoć u „odjeći ili novcu“ („obleki ali denarju”). Stanovao je u Gaćištu kod Suhopolja i molio da mu se nađe kakav zidarski posao u Zagrebu, gdje bi mogao bolje zaraditi. ${ }^{115}$ Općine su neko vrijeme pomagale slovenskim prognanicima, ali su zbog vlastitih teških prilika $s$ vremenom prestajale djelovati (ponajčešće zbog sukoba snaga NDH i partizana). Tako je bilo i s Općinom Gradište kod Županje, koja je do 1. ožujka 1942. pomagala izbjeglicama u hrani i ostalom jer „radimo teške poslove” (kopanje kanala). Dvije obitelji koje su bile smještene na tom području nakon prestanka dotoka te pomoći mole Odbor za pomoć. ${ }^{116}$

U Kakincu kod Bjelovara Franjo i Marija Videnšek svakih su četrnaest dana išli od kuće do kuće i radili za lokalno stanovništvo. ${ }^{117}$ Molili su odjeću. Odbor im je pronašao zaposlenje kod Franje Turkovića u Zagrebu. Franjo Videnšek trebao se brinuti o vinogradu i jednoj kravi, a njegova supruga trebala je pomagati u kući. Usto su dobili stan i 1.500 kuna plaće. ${ }^{118}$ To je uspješan primjer rješavanja egzistencijalnih potreba.

Pojedincima je nuđeno i zaposlenje u trgovinama oduzetim Srbima i Židovima. Tako je Andrija Kačičnik tražio da otkupi židovsku trgovinu u Osijeku koja je bila vlasništvo Rudolfa Krausa. Slovenski trgovci (ali i drugi - Hrvati,

\footnotetext{
112 Zanimljiva je obavijest o iseljenim Slovencima koji su umrli. Navedeni su: župnik Josip Lončarič, koji je umro u Varaždinu; Ivan Grgič, željezničar iz Maribora, umro je u Bosanskom Novom; Jereb Peter umro je u Ležimiru kod Hrvatske Mitrovice; Tomaž Majer iz Dobrave pri Bledu umro je u Banjoj Luci; Gizela Podgornik, službenica iz Maribora, umrla je u Španovici kod Pakraca; Simon Šturm iz Maribora umro je u Kukunjevcu kod Pakraca, a Ferdinand Razgoršek iz Šmartnog ob Paki u Mostaru. Navedeni su i oni koji su umrli, a za koje nije bilo podataka odakle su: Josip Šander, Ivana Šander, Karel Šander i Rafael Šander („Smrtna kosa med Slovenci v NDH”, Slovenec, 16. 1. 1943., 4). Tiskovina Slovenec izlazila je u Ljubljani i za vrijeme Drugoga svjetskog rata.

113 To je obično bila rubrika „Iz Hrvaške”, gdje se obavještavalo o novostima iz NDH povezanim sa Slovencima. Uglavnom su objavljivane pozitivne vijesti, o vjenčanjima ili zaposlenju. Tako npr. iz lista Slovenec od 10. rujna 1942. (str. 4) doznajemo da je Miha Prešeren iz Novog Mesta završio fakultet u Zagrebu i odmah dobio posao u Zavodu za kolonizaciju u Zagrebu. Osim njega zaposleni su bili i Olga Fikfak, Anton Sotler, Slavko Sotler, Franc Bukovec te Viktor Božič. Navode se primjeri i za sudsku i prosvjetnu službu („Iz Hrvaške”, Slovenec, 10. 5. 1942., 3 i dr.).

114 SI-AS-1899-SIOZ, kut. 1, 496/1943.

115 SI-AS-1899-SIOZ, kut. 1, 562/1943.

116 SI-AS-1899-SIOZ, kut. 3, 1626/1942.

117 SI-AS-1899-SIOZ, kut. 2, 292/1943.

118 SI-AS-1899-SIOZ, kut. 1, 3630/1942.
} 
Nijemci...) u to vrijeme mogli su kupovati oduzete srpske i židovske radnje za 25 posto vrijednosti. ${ }^{119}$ Marija Ozbek trebala je dobiti gostionicu u kotaru Tuzla. Međutim, nije prihvatila tu ponudu vidjevši da bi vrlo teško poslovala. Dodatni problem bilo je što u stanu nije bilo namještaja, u kuhinji posuđa, a promet je bio toliko malen da joj se ne bi isplatilo raditi. K tome Marija Ozbek nije imala novaca da kupi robu za gostionicu, djeca su joj bila premalena da bi radila s njom u lokalu, a suprug joj je bio teško bolestan. ${ }^{120}$ Neki su obrtnici ciljano tražili stručnjake koji su prisilno iseljeni iz Slovenije, ali je takvih upita bilo relativno malo. Stjepan Mijatović iz Đakova tražio je Odbor neka mu upute u Đakovo kožara koji ima pravo na otvaranje obrta, a on bi mu platio put i zaposlio ga kao poslovođu. ${ }^{121}$

Bilo je i onih koji su bili zaposleni, ali im plaća nije bila dovoljna da prežive (u ratu je to bio problem i brojnim Hrvatima i drugima). Naime, mnoge su obitelji živjele od jedne plaće, koja je jedva pokrivala prehranu dijela članova obitelji. Dirljive su i žalosne njihove molbe koje podnose Odboru. Jedna takva molba stigla je Odboru iz Osijeka. Ondje su u teškom položaju bile dvije obitelji. Četveročlana obitelj Marije Mljač, čiji suprug radi u ljevaonici u Osijeku, živjela je od samo 450 kuna tjedno. Jedan je njezin dječak, u dobi od sedam godina, bolestan, a za drugoga Marija nema odjeće i obuće. Obitelj Marije Bremec prisilno je iseljena iz okoline Žalca u Osijek, a živi sama s kćeri bez ikakve potpore, odnosno sa samo 500 kuna mjesečno, koliko kći zasluži. Odbor joj je poslao dva para cipela kao potporu. ${ }^{122}$ Nailazimo i na podatak da je molila Odbor neka joj se počne ponovo isplaćivati mirovina, koju nije dobivala. ${ }^{123}$ To su bili najčešći problemi koje su evidentirali i članovi Odbora. ${ }^{124}$

Rozalija Potuk bila je zaposlena u kotaru Grubišno Polje od ožujka 1942. godine. Sa svojom malom plaćom morala je izdržavati peteročlanu obitelj, pa je molila Odbor da joj pomogne oko izgubljene invalidnine koju bi trebao dobivati njezin otac, što bi svakako poboljšalo njihovu novčanu situaciju. ${ }^{125}$ Milka Kopitar stanovala je u Bistrici kraj Žepča i bila je jedina zaposlena od pet članova obitelji. No primila je tek jednu plaću iako je radila četiri mjeseca, pa je molila Hrvatski Crveni križ (koji je pismo proslijedio Odboru) novčanu pomoć da ju „spase iz ove moje bijede, da bi mogla nabaviti najpotrebnije, a to

\footnotetext{
SI-AS-1899-SIOZ, kut. 3, 1963/1942.

SI-AS-1899-SIOZ, kut. 3, 121/1941.

SI-AS-1899-SIOZ, kut. 1, 3357/1942.

SI-AS-1899-SIOZ, kut. 1, 3499/1942.

SI-AS-1899-SIOZ, kut. 3, 742/1942.

RICHTER, Delo Odbora, 10-11.

SI-AS-1899-SIOZ, kut. 3, 1918/1942.
} 
sve opet ne toliko radi mene, iako sam bolesna, koliko radi moje majke koja ima još troje neobskrbljene djece". ${ }^{126}$

Jozef Juvančič iz Giletinaca kod Nove Gradiške dobivao je za plaću 63 kune i 18 kg kukuruznoga brašna, pa piše Odboru da su on i supruga „više gladni nego siti”. ${ }^{127}$ Bilo je i dirljivih pisama koja su očito pisali prijatelji državnih službenika tražeći pomoć za svoje radnike slovenskoga podrijetla. Tako je za Franju Šajna, koji je dnevno zarađivao 48 kuna te s tim nije mogao preživjeti, reagirao predstojnik željezničke postaje u Zavidovićima, koji je molio Antu Vokića, ravnatelja Hrvatskih državnih željeznica u Sarajevu, neka tom čovjeku poveća plaću za 16 kuna. Molba za pomoć Šajnu stigla je i Odboru. ${ }^{128}$

Poseban je slučaj učiteljice ${ }^{129}$ Marije Zajec. Ona je prije rata bila učiteljica nedaleko od Ormoža. Iseljena je u Višnjicu kod Jasenovca, gdje je bila seoska učiteljica. No u selu je ostala bez plaće, što ju je dovelo do toga da je molila pomoć od Odbora. Marija Zajec bila je osim toga neudana, pa nije mogla samostalno preživjeti. ${ }^{130}$ Očito joj je Odbor pomogao da pronađe posao kao učiteljica u Prološcu kod Imotskog, a da se pojavi na novom radnome mjestu, dobila je od Odbora i 1.500 kuna za put. Nakon nekoga vremena željela je vratiti novac, ali nije uspjela zaštedjeti, pa se ispričava i moli neka joj se dug oprosti. ${ }^{131}$ Nije bila jedina, a Odbor je od početka svojega djelovanja pa do početka 1942. iseljenicima bespovratno razdijelio 225.118 kuna. Neki su pojedinci novac vratili, a neki nisu mogli iako su uredili svoj materijalni položaj. ${ }^{132}$

Neki su i prije deportacije iz Slovenije tražili zaposlenje u NDH. Anica Mervar još je 20. rujna 1941., znajući da će biti deportirana u NDH, iz Reichenburga poslala dopis Državnom ravnateljstvu za ponovu „kako može vršiti poštanske poslove na pošti ili raditi na brzojavu na željeznici”. Međutim, njezin je dopis proslijeđen Odboru, koji je za nju tražio zaposlenje. ${ }^{133}$

\footnotetext{
126 SI-AS-1899-SIOZ, kut. 4, 3099/1942.

127 SI-AS-1899-SIOZ, kut. 1, 3413/1942.

128 SI-AS-1899-SIOZ, kut. 4, 2071/1942.

129 Prema odredbi ministra nastave od 4. svibnja 1942., svi učitelji Slovenci bili su dužni nakon dvije godine rada u državnoj službi položiti dodatni dopunski ispit iz hrvatskoga jezika s književnošću, hrvatske povijesti, zemljopisa NDH i školske uprave s poznavanjem cjelokupnoga zakonodavstva koje se odnosi na pučke škole (MATAIĆ, Zakoni, zakonske odredbe i narodbe proglašene od 1. svibnja od 12. svibnja 1942., 252.

130 SI-AS-1899-SIOZ, kut. 3, 92/1941.

131 SI-AS-1899-SIOZ, kut. 4, 2942/1942.

132 RICHTER, Delo Odbora, 10.

133 SI-AS-1899-SIOZ, kut. 1. 3418/1942
} 


\section{Problem mirovina}

Odbor je pomagao pojedincima da ostvare svoju mirovinu i plaću, ali i da pronađu zaposlenje. Bilo je uobičajeno da se i državni činovnici smjeste u sela gdje nisu mogli pronaći zaposlenje. Tako je obitelj Andreja Drolle, ${ }^{134}$ namještenika socijalnoga osiguranja, prisilno iseljena iz Celja u Ćeralije kod Podravske Slatine. Ondje nije mogao naći posao, pa je tražio premještaj u neki drugi dio NDH ili povratak u Celje. ${ }^{135}$

Problem je bila i isplata mirovina. Umirovljeni državni službenik Rudolf Polak bio je prisilno iseljen u Begov Han kod Žepča. On piše Odboru da nakon prisilnoga iseljavanja nije primio nijednu mirovinu. Mirovinu je zahtijevao od Državnoga ravnateljstva za ponovu, ali, koliko je vidljivo iz dopisa, oni su tražili dopunu zahtjeva. Stoga on traži ubrzavanje rješavanja njegove molbe budući da je star i da ni on ni supruga nemaju više snage ni za kakav rad. ${ }^{136}$ Slične su probleme imali i slovenski umirovljenici u Travniku. ${ }^{137}$ Jedan od prvih zadataka Odbora bio je napraviti popis umirovljenika te ga predati Državnom ravnateljstvu za ponovu da bi umirovljenici dobili svoje mirovine. ${ }^{138}$

\section{Molbe za povratak kući}

Brojni dopisi Odboru pokazivali su koliko su se Slovenci željeli vratiti kući. Važna je priča Marije Kralj, koja je 19. srpnja 1941. prisilno iseljena iz Lahonaca kod Ormoža. Njezin suprug toga dana nije bio kod kuće jer je negdje radio kao zidar. Ona je s petero djece prisilno iseljena u Novu Gradišku i ondje je živjela od tuđe milosti. Nijemci nisu odobrili Mariji da se vrati suprugu u Lahonce, a ona je tražila pomoć od Odbora u odjeći i obući za djecu koja su bila u dobi između dvije i sedam godina. Iznad dopisa napisano je „hitno“ („nujno”). ${ }^{139}$

Želja za povratkom kući bila je velika. Slovenci u NDH koji su djelovali u legalnim društvima pomagali su koliko su mogli. Tako je npr. Slovenska kmečko-delavska sloga, koja je djelovala u Zagrebu, osnovala i zadrugu „Triglav", koja se bavila otkupom voća i povrća te ga izvozila u Treći Reich. Ujedno je zadruga posredovala te je mnoge Slovence poslala na rad u Treći Reich, čime ih je neizravno vraćala u njihov zavičaj. Slovenska kmečko-delavska sloga

\footnotetext{
134 Bio je aktivan član „Delavske zbornice” u Celju („Celje”, Nova pravda /Celje/, 13. 3. 1938., 3). Nakon Drugoga svjetskog rata vratio se u Celje te je i dalje bio aktivan u javnom životu.

135 SI-AS-1899-SIOZ, kut. 4. 2099/1942

136 SI-AS-1899-SIOZ, kut. 3, 510/1941.

137 ŠKILJAN, Organizirana prisilna iseljavanja Srba iz NDH, 297.

138 RICHTER, Delo Odbora, 6.

139 SI-AS-1899-SIOZ, kut. 1, 68/1943.
} 
djelovala je i kao posrednička ustanova preko koje se određeni broj prognanih Slovenaca i slovenskih svećenika ipak uspio vratiti kući. ${ }^{10}$ Ipak, nisu svi bili toliko sretni u svojim nastojanjima. Povratak kući molio je i Alojz Horvath, koji je živio u Grbavcu kod Grubišnog Polja, a želio je natrag u Sveti Lenart na Slovenskim goricama. Slao je molbu njemačkom konzulatu, ali nije dobio odgovor, a navodi da su njegovi rođaci dobili dozvolu za povratak, pa to želi i on. ${ }^{141}$

\section{Molbe za pomoć u zdravstvenim uslugama}

I osnovne zdravstvene usluge često su bile nedostižne za slovenske prognanike. Primjer je molba Ivana Gašperiča iz Bosanske Gradiške, koji je najprije molio pomoć za naočale za svoju kćer. Od Odbora je dobio financijsku pomoć od 600 kuna. Međutim, morao je platiti 200 kuna pregled i 200 kuna smještaj u Zagrebu, pa mu nije ostalo dovoljno za dječje naočale. Stoga ponovno traži Odbor novčanu pomoć da kupi naočale. ${ }^{142}$

Pojedinci su bili u teškom zdravstvenom stanju, pa su tražili potporu za liječenje. Franc Majhen preseljen je iz Svetoga Vida pri Ptuju u Sanski Most 13. srpnja 1941. godine. Potom je u rujnu 1941. premješten u Varaždin, gdje je dobio službu. Supruga mu je oboljela od tuberkuloze, a prema preporuci liječnika trebala je otići na oporavak u bolnicu za plućne bolesnike u Klenovniku. Iz pisma je vidljivo da je Majhen dnevno zarađivao samo 60 kuna te se može zaključiti da je liječenje, koje je stajalo 200 kuna dnevno, za njega bilo apsolutno nedostižno bez pomoći. Navodi da je uspio prikupiti 4.000 kuna, ali moli Odbor dodatnih 2.000 kuna. $^{143}$

\section{Zaključak}

Problematika vezana uz prognano slovensko stanovništvo koje je jedno razdoblje svojega života provelo na prostoru Hrvatske, Bosne i Hercegovine te Srbije do sada nije potpuno istražena. Prema pregledu postojećih istraživanja i literature, vidljivo je da ju povjesničari, hrvatski, slovenski i srpski, povezuju s iseljavanjem i progonom ostaloga (prije svega srpskoga i židovskoga) stanovništva te se ta tema u knjigama i raspravama često spominje usputno u kontekstu međuetničkih sukoba. Suvremeni slovenski povjesničari nisu se

\footnotetext{
140 KARAKAŠ OBRADOV, Novi mozaici nacija, 206.

141 SI-AS-1899-SIOZ, kut. 2, 607/1943.

142 SI-AS-1899-SIOZ, kut. 1, 3217/1942.

143 SI-AS-1899-SIOZ, kut. 4, 2191/1942.
} 
intenzivno bavili tom tematikom. Posljednja opsežnija istraživanja slovenskih povjesničara provođena su osamdesetih godina XX. stoljeća.

Potrebno je naglasiti da na prostor NDH nije bilo iseljeno onoliko stanovnika koliko je u samom početku bilo planirano, ali iako je broj prognanika bio mnogo manji, vlasti u NDH imale su problema osigurati osnovne egzistencijalne uvjete da bi prognane obitelji mogle živjeti. Nedostajalo je svega: od hrane, odjeće i obuće do zdravstvenih potrepština. Zbog nedovoljnih izvora te preseljavanja Slovenaca i nakon što su došli na prostor NDH, a prije svega zbog odlazaka iz Bosne i Hercegovine u Slavoniju, ali i s obzirom na to su se neke obitelji selile više puta (zabilježeno je čak i do osam puta), nije moguće detaljnije prikazati u kojim je kotarevima situacija bila teža ili lakša. Činjenica je da su slovenski prognanici živjeli u teškim ratnim uvjetima te u dodatno otežanom položaju jer je i lokalno stanovništvo prema njima imalo otpor i strah. Bili su prepušteni sami sebi i dijelom državnim institucijama koje su se trebale brinuti za njih (Državno ravnateljstvo za ponovu, kotarske oblasti, velike župe...). U cijeloj toj situaciji vrlo važnu ulogu imao je i Odbor za slovenske useljenike, koji je pomagao Slovencima u NDH na svaki način u okviru svojih mogućnosti. Radilo se najčešće o novčanoj pomoći, pomoći u hrani, obući i odjeći, pomoći oko ostvarivanja statusa (zaposlenje ili mirovina) i slično. Tisuće pisama koje su mu stizale pokazuju koliko je Odbor bio važna (vrlo vjerojatno najčešće i jedina) institucija kojoj su se slovenski iseljenici obraćali. Veliki dio Slovenaca bio je izložen različitim teškim egzistencijalnim problemima jer su bili iseljeni iz svojih domova, jer su došli na područje gdje je bio rat i zato što vlasti NDH nisu na njih gledale s povjerenjem.

Brojne slovenske obitelji koje su bile „istrgnute” iz svojih sredina, najčešće izolirano ili u manjim grupama naseljene u strane krajeve i u kuće nekih drugih (srpskih) iseljenika sasvim su sigurno imale različite traume. Koliko su se slabo integrirali u novu sredinu govori i činjenica da je nakon završetka Drugoga svjetskog rata u repatrijaciji sudjelovalo više Slovenaca od zabilježenog broja iseljenih. ${ }^{144}$ Integrirali su se tek pojedinci koji su u NDH zasnovali obitelj i pronašli stalno zaposlenje. S novoprognanim Slovencima u Sloveniju su se vraćali i Slovenci koji su na prostoru Hrvatske, Bosne i Hercegovine te Srbije živjeli i prije početka Drugoga svjetskog rata.

Iz pisama Odboru koja su odabrana kao primjeri u ovom članku jasno je vidljivo kako su bijedno slovenski iseljenici živjeli u novom kraju i koliko ih je bilo mnogo koji su jedva krpali kraj s krajem. Oskudice, bolesti, pa i umiranja od gladi, osobito u Bosni, bilo je tijekom rata i među domaćim stanovništvom.

144 Samo do 31. kolovoza 1945. preko Ekonomskoga odsjeka Mjesnog odbora Oslobodilačke fronte repatrirano je 7000 Slovenaca. Bilo je mnogo onih koji su se u Sloveniju vraćali i mimo toga odbora (FERENC, Nacistička politika denacionalizacije u Sloveniji, 411). 
Žestina vojnih djelovanja na području NDH bila je velika, pa je tijekom cijeloga rata izbjeglo i iznimno mnogo Hrvata i muslimanskoga stanovništva. Srpsko stanovništvo koje je bilo izloženo progonima često je živjelo u zbjegu (uz iseljavanje, protjerivanje i dr.). Tračak nade za prisilno iseljene Slovence, koji su ponekad bili i stotine kilometara daleko od svojih domova, bio je Odbor i ljudi koji su ondje odlučivali na koji će način pomoći svojim sunarodnjacima.

Tema je važna za hrvatsku i slovensku povijest te bi, s obzirom na to da još uvijek postoje neposredni akteri tih progona koji se sjećaju kakve su teškoće prolazili članovi njihovih obitelji i oni sami, bilo potrebno raširiti istraživanje i temu valorizirati te joj dati primjeren prostor u hrvatskoj i europskoj historiografiji.

\section{Arhivski i neobjavljeni izvori}

HR-HDA-1076: Ministarstvo državne riznice NDH. Odjel za novčarstvo, državnu imovinu i dugove. Ured za podržavljeni imetak, Srpski odsjek.

SI-AS-1899-SIOZ: Slovenija, Arhiv Republike Slovenije, fond 1899, Slovenski izseljeniški odbor Zagreb, 1941-1945.

SI-AS-1907-UPL NDH: Slovenija, Arhiv Republike Slovenije, fond 1907, Urad za podržavljeno lastnino Nezavisne države Hrvatske v Zagrebu (1941-1945).

\section{Tisak}

Delo (Ljubljana), 1981.

Jutro (Ljubljana), 1942, 1944.

Nova pravda (Celje), 1938.

Savinjski vestnik (Celje), 1952.

Slovenec (Ljubljana), 1941-1943.

Službeni list (Beograd), 1939.

Vigred - Vestnik - Prosvetni oder (Ljubljana), 1944.

\section{Literatura}

AKMADŽA, Miroslav. Krunoslav Draganović: iskazi komunističkim istražiteljima. Slavonski Brod: Hrvatski institut za povijest, Podružnica za povijest Slavonije, Srijema i Baranje, 2010. 
ARMANDA, Ivan. „Nadbiskup Alojzije Stepinac i zbrinjavanje prognanih slovenskih konventualaca u Drugom svjetskom ratu". Razprave in gradivo (2018), br. 80: 5-20.

BADE, Klaus J. Evropa v gibanju: migracije od poznega 18. stoletja do danes. Ljubljana: Založba, 2005.

BATELJA, Juraj. Blaženi Alojzije Stepinac i prognani slovenski svećenici u Drugome svjetskom ratu. Zagreb: Postulatura blaženoga Alojzija Stepinca, 2018.

BRČIĆ, Rafael. „O iseljavanju Slovenaca u Bosnu 1941. godine”. Prilozi (Sarajevo) 9 (1973), br. 1: 301-314.

COLNAR, Peter. „Kdo je pomagal izgnancem v Zagrebu?”. U: Izgnanci, ur. Franc Šetinc. Ljubljana: Društvo izgnancev Slovenije, 1993, 301-303.

„Draganović, Krunoslav”. U: Hrvatska enciklopedija (on-line). Leksikografski zavod „Miroslav Krleža”. Pristup ostvaren 5. 6. 2020. http://www.enciklopedija.hr/Natuknica.aspx?ID=16116.

FERENC, Tone. Nacistička politika denacionalizacije u Sloveniji u godinama od 1941. do 1945. Ljubljana; Beograd: Partizanska knjiga, 1979.

FERENC, Tone. Okupacijski sistemi na Slovenskem 1941-1945. Ljubljana: Modrijan, 1997.

FERENC, Tone. „Razvoj prebivalstva: druga svetovna vojna na Slovenskem 19411945”. U: Slovenska novejša zgodovina: od programa Zedinjena Slovenija do mednarodnega priznanja Republike Slovenije 1848-1992., ur. Jasna Fischer i dr. Ljubljana: Mladinska knjiga; Inštitut za novejšo zgodovino, 2005, 576-577.

GRBEŠIĆ, Grgo. „Prihvat prognanih slovenskih svećenika u Đakovačkoj i Srijemskoj biskupiji 1941. godine”. Diacovensia: teološki prilozi 10 (2002), br. 1: 131-150.

HEĐBELI, Živana. „Ponova - Arhivsko gradivo Ureda za podržavljeni imetak Nezavisne Države Hrvatske”. Ljetopis SKD Prosvjeta 4 (2001): 511-521.

HOJAN, Tatjana. „Cvetko, Vladimir”. U: Novi Slovenski biografski leksikon (on-line). Slovenska akademija znanosti in umetnosti, Znanstvenoraziskovalni center SAZU. Pristup ostvaren 5. 6. 2020. https://www.slovenska-biografija.si/oseba/ sbi1021680/.

HUZJAN, Vladimir. „Slovenci u Varaždinu tijekom 1941. i 1942. godine”. Razprave in gradivo (2019), br. 82: 85-110.

JELIĆ-BUTIĆ, Fikreta. Ustaše i NDH. Zagreb: Sveučilišna naklada Liber; Školska knjiga, 1997.

KARAKAŠ OBRADOV, Marica. „Migracije Slovencev na hrvaško območje v drugi svetovni vojni (izseljevanje in izgnanstvo)". Prispevki za novejšo zgodovino 52 (2012), br. 2: 139-1474 
KARAKAŠ OBRADOV, Marica. Novi mozaici nacija u „novim poredcima”. Zagreb: Hrvatski institut za povijest, 2014.

KEVO, Mario, prir. Veze Međunarodnog odbora Crvenog križa i Nezavisne Države Hrvatske. Dokumenti, knj. 1. Slavonski Brod; Zagreb; Jasenovac: Hrvatski institut za povijest; Spomen-područje Jasenovac, 2009.

KRAMAR, Alojz. Slovenski izgnanci v Neodvisni državi Hrvaški. Zagreb: Vijeće slovenske nacionalne manjine Grada Zagreba, 2016.

LISAC, Andrija Ljubomir. „Deportacija Srba iz Hrvatske 1941. godine”. Historijski zbornik 1 (1956): 125-145.

MATAIĆ, Adam (ur.). Zakoni, zakonske odredbe i naredbe proglašene od 30. listopada do 20. studena 1941. Knjiga VIII. Zagreb: Knjižare St. Kugli. (http://www. sistory.si/cdn/publikacije/37001-38000/37532/zakoni_zakonske_odredbe_i_naredbe_VIII.pdf)

MATAIĆ, Adam (ur.). Zakoni, zakonske odredbe i narodbe proglašene od 1. svibnja od 12. svibnja 1942. Knjiga XVI. Zagreb: Knjižare St. Kugli. (https://www.sistory.si/ cdn/publikacije/37001-38000/37502/zakoni_knjiga_XVI.pdf).

MILOŠEVIĆ, Slobodan. Izbeglice i preseljenici na teritoriji okupirane Jugoslavije 19411945. Beograd: IRO Narodna knjiga; Institut za savremenu istoriju Beograd, 1981.

REPE, Božo. „Izgon (Usoda slovenskih izgnancev med leti 1941-1945)”. U: Migracije in slovenski prostor od antike do danes, ur. Peter Štih i Bojan Balkovec. Ljubljana: Zveza zgodovinskih društev Slovenije, 2010., 245-256.

RICHTER, Jakob. Delo Odbora za slovenske useljenike v Zagrebu. Zagreb: [Odbor za slovenske useljenike], 1943.

RIMAN, Barbara. „Delovanje Slovencev v Osijeku med drugo svetovno vojno”. Razprave in gradivo (2016), br. 77: 137-154.

RIMAN, Barbara. Slovenska društva u Hrvatskoj od 1886. do 1991. godine. Ljubljana: Inštitut za narodnostna vprašanja; Vijeće slovenske nacionalne manjine Primorsko-goranske županije, 2019.

RIMAN, Barbara; RIMAN, Kristina. „Pavle Horvat u kontekstu slovensko-hrvatskih političkih odnosa od 1918. do 1945. i njegova književna obrada”. Časopis za suvremenu povijest 51 (2019), br. 1: 233-251.

RYBA ̌̌, Miloš. „Izgoni slovenskih duhovnikov leta 1941.” U: Izgnanci, ur. Franc Šetinc. Ljubljana: Društvo izgnancev Slovenije, 1993, 117-129.

ŠETINC, Franc, ur. Izgnanci. Ljubljana: Društvo izgnancev Slovenije, 1993.

ŠKILJAN, Filip. Organizirana prisilna iseljavanja Srba iz NDH. Zagreb: Srpsko narodno vijeće, 2014.

ŠKILJAN, Filip. „Prisilno iseljavanje Srba iz Podravine i Kalničkog prigorja u ljeto i ranu jesen 1941." Cris 14 (2012), br. 1: 342-364. 
ŠKVORČEVIĆ, Antun. Gostoprimstvo Katoličke crkve prognanim slovenskim svećenicima u Požegi (1941. - 1942.). Zagreb: Biskupski ordinarijat, 2008.

VUKIČEVIĆ, Slavko (ur). Zločini na jugoslovenskim prostorima u Prvom i Drugom svetskom ratu. Zbornik dokumenata. Zločini Nezavisne Države Hrvatske 19411945. Beograd: Vojnoistorijski institut, 1993.

ŽNIDARŠIČ, Ivica; KAPLAN, Zdenka, ur. Spomini in pričevanja. Ljubljana: Društvo izgnancev Slovenije, 2003.

ŽNIDARŠIČ, Ivica; KAPLAN, Zdenka, ur. Spomini in pričevanja II. Ljubljana: Društvo izgnancev Slovenije, 2006.

ŽNIDARŠIČ, Ivica; KAPLAN, Zdenka, ur. Spomini in pričevanja III. Ljubljana: Društvo izgnancev Slovenije, 2012. 


\section{SUMMARY}

\section{Slovene Displaced Persons in the Independent State of Croatia}

The problem of the expelled Slovene population from the areas occupied by the Third Reich during World War II is present in Croatian, Slovene, and Serbian history, but is primarily linked to the emigration and expelling of the population of other ethnicities (mostly Serbian). This phase of Slovene history is not well-known to the broader public in Croatia. Therefore, the aim of this paper is to highlight the large number of Slovenes who survived World War II on the territory of Croatia and Bosnia and Herzegovina, i.e. then the territory of the Independent State of Croatia, which had different borders than Croatia and Bosnia and Herzegovina today. Papers on the topic of the Slovene population displaced to Croatia and Bosnia and Herzegovina often do not consider the cultural shock that the displaced persons suffered. Apart from describing the activities of the institutions that were legal and responsible for providing for the expelled Slovene population, this paper also presents individual cases that exemplify the difficult situation and problems faced by those expelled from Slovene lands.

Key words: World War II; Independent State of Croatia; Slovenes; forced migrations; Slovene displaced persons 